\title{
Insight into adsorption equilibrium, kinetics and thermodynamics of lead onto alluvial soil
}

\author{
B. Das $\cdot$ N. K. Mondal $\cdot$ R. Bhaumik $\cdot$ \\ P. Roy
}

Received: 13 November 2011/Revised: 16 February 2012/ Accepted: 16 March 2013/Published online: 17 April 2013

(C) Islamic Azad University (IAU) 2013

\begin{abstract}
In the present study, adsorption of lead (II) ions from aqueous solution by alluvial soil of Bhagirathi River was investigated under batch mode. The influence of solution $\mathrm{pH}$, sorbent dose, initial lead (II) concentration, contact time, stirring rate and temperature on the removal process were investigated. The lead adsorption was favored with maximum adsorption at $\mathrm{pH}$ 6.0. Sorption equilibrium time was observed in $60 \mathrm{~min}$. The equilibrium adsorption data were analyzed by the Freundlich, Langmuir, DubininRadushkevich and Temkin adsorption isotherm models. The kinetics of lead (II) ion was discussed by pseudo firstorder, pseudo second-order, intra-particle diffusion, and surface mass transfer models. It was shown that the adsorption of lead ions could be described by the pseudo second-order kinetic model. The activation energy of the adsorption process $\left(E_{\mathrm{a}}\right)$ was found to be $-38.33 \mathrm{~kJ} \mathrm{~mol}^{-1}$ using the Arrhenius equation, indicating exothermic nature of lead adsorption onto alluvial soil. Thermodynamic parameters, such as Gibbs free energy $\left(\Delta G^{0}\right)$, the enthalpy $\left(\Delta H^{0}\right)$, and the entropy change of sorption $\left(\Delta S^{0}\right)$ have also been evaluated and it has been found that the adsorption process was spontaneous, feasible, and exothermic in nature. The results indicated that alluvial soil of Bhagirathi
\end{abstract}

The present research work started from the beginning of 2010 and ended in the middle of September 2011.

The entire work has been conducted in the Department of Environmental Science with the active help of Chemistry Department and Instrumentation Department, Burdwan University, West Bengal, India.

B. Das · N. K. Mondal $(\bowtie) \cdot$ R. Bhaumik · P. Roy

Department of Environmental Science,

The University of Burdwan, Burdwan, India

e-mail: nkmenvbu@gmail.com
River can be used as an effective and low cost adsorbent to remove lead ions from aqueous solutions.

Keywords Activation energy - Adsorption isotherms and kinetics $\cdot$ Lead (II) ion · Surface mass transfer

\section{Introduction}

The removal of heavy metals from aqueous solutions is one of the most important environmental concerns due to their high toxicity and impact on human health. Lead poisoning in human causes severe damage to the nervous system and affects the function of brain cells (Ho et al. 2001). It is also a general metabolic poison and enzyme inhibitor ( $\mathrm{Li}$ et al. 2002). Many industries, such as painting, petrochemical, newsprint, smelting, metal electroplating, mining, plumbing, and battery industries are the major sources of lead pollution. The permissible level for lead in drinking water is $0.05 \mathrm{mg} / \mathrm{L}$ (WHO 1996). The permissible limit ( $\mathrm{mg} / \mathrm{L}$ ) for $\mathrm{Pb}$ (II) in wastewater according to Bureau of Indian Standards (BIS) is $0.1 \mathrm{mg} / \mathrm{L}$ (BIS 1981). Therefore, the concentrations of lead must be reduced to levels that satisfy environmental regulations for various bodies of water. The common methods for removing metal ions from water and wastewater include chemical precipitation, ion exchange, electrochemical deposition, solvent extraction, membrane filtration, and adsorption. Among these, adsorption is effective and economical (Ahmad et al. 2009). Many heavy metal adsorption studies have focused on the application of activated carbons (Kikuchi et al. 2006; Malik et al. 2002). The discovery of alternative adsorbent to replace the costly activated carbon is highly encouraged. Nowadays, researchers are focusing more on the development of low cost and efficient adsorbents to remove heavy metals from 
aqueous solution. A number of researchers have utilized wide variety of adsorbents to remove heavy metal ions from aqueous solutions. Some of the recent developments include adsorbents like, wood ash (Malakootian et al. 2008), rice husk (Akhtar et al. 2010), clay (Papini et al. 2002), slag (Dimitrova and Mehandgiev 1998), peat (Blais et al. 2002), goethite (Abdel-Samad and Watson 1998), gibbsite (Weerasooriya et al. 2001)), red mud (Gupta et al. 2001), lateritic minerals (Ahmad et al. 2002), and calcareous soil (Das and Mondal 2011) for the removal of lead ions from aqueous solution.

In this study, alluvial soil which was obtained from the river Bhagirathi, West Bengal, India was investigated as a potential and low cost adsorbent for the removal of $\mathrm{Pb}$ (II) ions from aqueous solutions. The objective of the present work was to study the possibility of utilizing alluvial soil from the Bhagirathi river (ASBR) as an adsorbent for removing lead ions from aqueous solutions. The effect of various experimental parameters, such as adsorbent dose, initial lead (II) concentration, contact time, stirring rate, temperature, and $\mathrm{pH}$ were investigated. Adsorption kinetics, isotherms, and thermodynamic parameters were also evaluated and reported.

\section{Materials and methods}

Preparation of the synthetic sample

All the reagents used for the current investigation were of GR grade from E. Merck Ltd., India. Lead nitrate $\left[\mathrm{Pb}\left(\mathrm{NO}_{3}\right)_{2}\right]$ stock solution of $100 \mathrm{mg} / \mathrm{L}$ concentration was prepared and the working solutions were made by diluting the former with double distilled water. The range in concentrations of lead (II) ions prepared from standard solution varied between 25 and $100 \mathrm{mg} / \mathrm{L}$. Before mixing the adsorbent, the $\mathrm{pH}$ of each lead solution was adjusted to the required value by $0.1 \mathrm{M} \mathrm{NaOH}$ or $0.1 \mathrm{M}$ $\mathrm{HCl}$ solution.

\section{Adsorbent collection and preparation}

Alluvial soil used in this study was collected from the banks of River Bhagirathi owing to its high alluvial soil content and low permeability. The Bhagirathi River is one of the main river in Murshidabad, Burdwan, Nadia, and Hooghly districts in the Indian state of West Bengal. The alluvial soil sample was not purified prior to usage. It was initially sun-dried for 7 days followed by drying in hot air oven at $383 \pm 1 \mathrm{~K}$ for 2 days. The dried soil was crushed and sieved to give a fraction of 250-mesh screen and then stored in sterile, closed glass bottles and used as an adsorbent.

\section{Adsorbent characterization}

Adsorbent characterization was performed by means of spectroscopic and quantitative analysis. The surface area of the adsorbent was determined by Quantachrome surface area analyzer (model- NOVA 2200C). Alumina was estimated by wet chemical analysis method (Vogel 1984). The $\mathrm{pH}$ of aqueous slurry was determined by soaking $1 \mathrm{~g}$ of ASBR in 50-mL distilled water, stirred for $24 \mathrm{~h}$ and filtered and the final pH was measured (Hanafiah et al. 2009). Concentration of lead in alluvial soil sample was determined by digestion method (Naeem et al. 2010). The physico-chemical characteristics of the adsorbent were determined using standard procedures (Saha and Sanyal 2010). The percentage of clay, silt, and sand was determined by hydrometric method (Saha and Sanyal 2010). The cation exchange capacity (CEC) of the alluvial soil sample was determined by the ammonium acetate method (Rhoades 1982). The concentrations of sodium and potassium were determined by Flame Photometer (Model No. SYSTRONICS 126) while magnesium, calcium, and residual lead (II) concentrations were determined by atomic absorption spectrophotometer (Model No. GBC HG 3000). For stirring purpose, magnetic stirrer (TARSONS, Spinot digital model MC02, CAT No. 6040, S. No. 173) is used. The $\mathrm{pH}$ of zero point charge or $\mathrm{pH}_{\mathrm{ZPC}}$ was determined based on the previous method (Mondal 2009). The Fourier transform infrared (FTIR) spectra of ASBR were recorded with Fourier transform infrared spectrophotometer (PERKIN-ELMER, FTIR, Model-RX1 Spectrometer, USA) in the range of $400-4,000 \mathrm{~cm}^{-1}$. X-ray diffraction analysis of the adsorbent was carried out using X-ray diffractometer equipment (Model Philips PW 1710) with a Cobalt target at $40 \mathrm{kV}$. In addition, scanning electron microscopy (SEM) analysis was carried out using a scanning electron microscope (HITACHI, S-530, Scanning Electron Microscope and ELKO Engineering, B.U. BURDWAN) at $15 \mathrm{kV}$ to study the surface morphology of the adsorbent.

Batch adsorption procedure

Batch adsorption studies were carried out in 250-mL glassstoppered Erlenmeyer flasks with $50 \mathrm{~mL}$ of the working solution of lead (II) ions with a concentration of $25 \mathrm{mg} / \mathrm{L}$. A weighed amount (2.0 g) of adsorbent was added to the solution. The flasks were agitated at a constant speed of $800 \mathrm{rpm}$ for $90 \mathrm{~min}$ in a magnetic stirrer at $313 \pm 1 \mathrm{~K}$. The influence of $\mathrm{pH}(2.0-8.0)$, initial lead concentration $\left(25,50,75\right.$, and $\left.100 \mathrm{mgL}^{-1}\right)$, contact time $(5,10,15,20$, $25,30,45,60$, and $90 \mathrm{~min})$, adsorbent dose $(0.5,1,2$, $2.5 \mathrm{~g} / 50 \mathrm{~mL}$ ) was evaluated during the present study. Samples were collected from the flasks at predetermined 
time intervals for analyzing the residual lead concentration in the solution. The amount of lead ions adsorbed in milligram per gram was determined using the following mass balance equation:

$q_{\mathrm{e}}=\frac{\left(C_{\mathrm{i}}-C_{\mathrm{e}}\right) V}{m}$

where $C_{\mathrm{i}}$ and $C_{\mathrm{e}}$ are lead concentrations $(\mathrm{mg} / \mathrm{L})$ before and after adsorption, respectively, $V$ is the volume of adsorbate in liter and $m$ is the weight of the adsorbent in grams. The percentage of removal of lead ions was calculated from the following equation:

$\operatorname{Removal}(\%)=\frac{\left(C_{\mathrm{i}}-C_{\mathrm{e}}\right)}{C_{\mathrm{i}}} \times 100$

\section{Desorption experiments}

For the desorption study, $2.0 \mathrm{~g}$ of ASBR was first treated with $50 \mathrm{~mL}$ of $25 \mathrm{mg} / \mathrm{L}$ of $\mathrm{Pb}$ (II) ions solution for $1 \mathrm{~h}$. After adsorption experiment, ASBR was collected by filtration and washed with distilled water for three times to remove excess lead (II) ions. Then the exhausted ASBR was contacted with $50 \mathrm{~mL}$ of different concentrations (0.05, 0.1, 0.3, and $\left.0.5 \mathrm{~mol} \mathrm{~L}^{-1}\right)$ of different desorbing solutions $\left(\mathrm{HNO}_{3}\right.$ and $\left.\mathrm{HCl}\right)$. The mixture was stirred at $800 \mathrm{rpm}$ for $90 \mathrm{~min}$, filtered and analyzed. The percentage of desorption $\left(D_{\mathrm{p}}\right)$ of lead (II) ions was calculated from the following equation:

$D_{\mathrm{p}}=\left(\frac{m_{\mathrm{r}}}{m_{0}}\right) \times 100$

Where $m_{\mathrm{r}}$ is the amount of lead (II) ions desorbed (mg), and $\mathrm{m}_{\mathrm{o}}$ is the amount of lead (II) ions adsorbed (mg).

\section{Results and discussion}

\section{Characterization of ASBR}

The ASBR was found to be stable in water, dilute acids, and bases. The adsorbent behaves as neutral at $\mathrm{pH}$ zero charge. Adsorption of cation is favored at $\mathrm{pH}>\mathrm{pHzpc}$, while the adsorption of anion is favored at $\mathrm{pH}<\mathrm{pHzpc}$ (Mondal 2009). The point of zero charge is 4.75 (Fig. 1) irrespective of difference in concentration of $\mathrm{HNO}_{3}$ used. The physico-chemical properties of ASBR are summarized in Table 1.

The FTIR spectrum of ASBR (Fig. 2) displays a number of absorption peaks indicating the presence of different types of functional groups. The broad and strong band at $3,438 \mathrm{~cm}^{-1}$ indicates the presence of $-\mathrm{OH}$ stretching. Two sharp peaks observed at 2,924 and $2,854 \mathrm{~cm}^{-1}$ could be assigned to asymmetric and symmetric $\mathrm{CH}_{2}$ group

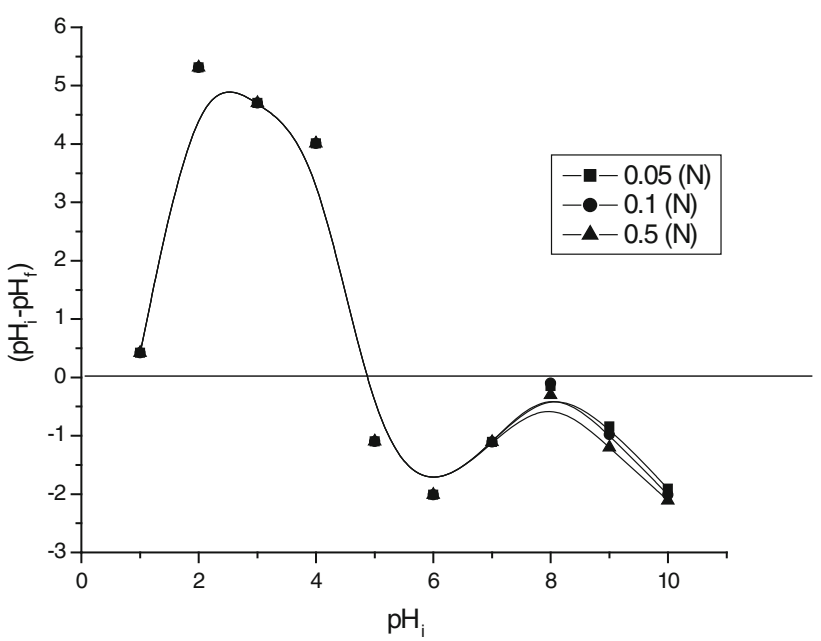

Fig. 1 pH of zero point charge of ASBR (experimental conditions: (adsorbent dose $1.5 \mathrm{~g}$ in $100 \mathrm{~mL}$, temperature $313 \mathrm{~K}$ )

Table 1 Physico-chemical characteristics of ASBR

\begin{tabular}{|c|c|}
\hline Analysis & Value \\
\hline $\mathrm{pH}_{\text {slurry }}$ & 6.5 \\
\hline $\mathrm{pH}_{\mathrm{zpc}}$ & 4.75 \\
\hline Specific gravity & 0.81 \\
\hline Moisture content $(\%)$ & 0.53 \\
\hline Bulk density $\left(\mathrm{g} \mathrm{cm}^{-3}\right)$ & 1.351 \\
\hline Particle density $\left(\mathrm{g} \mathrm{cm}^{-3}\right)$ & 2.44 \\
\hline Porosity (\%) & 44.63 \\
\hline Clay $(\%)$ & 3.08 \\
\hline Silt $(\%)$ & 9.1 \\
\hline Sand $(\%)$ & 81 \\
\hline $\mathrm{Al}_{2} \mathrm{O}_{3}(\%)$ & 6.8 \\
\hline Conductivity $(\mu \mathrm{S} / \mathrm{cm})$ & 2.0 \\
\hline BET surface area $\left(\mathrm{m}^{2} / \mathrm{g}\right)$ & 6.8 \\
\hline Micropore area $(\%)$ & 32.5 \\
\hline Cation exchange capacity (meq $\mathrm{g}^{-1}$ ) & 48 \\
\hline $\mathrm{Na}^{+}\left(\mathrm{mg} \mathrm{L}^{-1}\right)$ & 61.15 \\
\hline $\mathrm{K}^{+}\left(\mathrm{mg} \mathrm{L}^{-1}\right)$ & 16.7 \\
\hline $\mathrm{Ca}^{2+}\left(\mathrm{mg} \mathrm{L}^{-1}\right)$ & 0.4 \\
\hline $\mathrm{Mg}^{2+}\left(\mathrm{mg} \mathrm{L}^{-1}\right)$ & 11.6 \\
\hline $\mathrm{PO}_{4}{ }^{3-}\left(\mathrm{mg} \mathrm{L}^{-1}\right)$ & 0.817 \\
\hline $\mathrm{Pb}^{2+}\left(\mathrm{mg} \mathrm{L}^{-1}\right)$ & BDL \\
\hline
\end{tabular}

$B D L$ below detection limit

(Hanafiah et al. 2009). The variable peak at $1,636 \mathrm{~cm}^{-1}$ was attributed to stretching vibration of $\mathrm{C}=\mathrm{C}$ alkene group. The characteristic band at $1,024 \mathrm{~cm}^{-1}$ corresponds to $\mathrm{C}-\mathrm{O}$ stretching vibration (Arief et al. 2008). The peaks at 528 and $778 \mathrm{~cm}^{-1}$ show the presence of $\mathrm{C}-\mathrm{Br}$ stretching and $\mathrm{C}-\mathrm{Cl}$ stretching vibration (Coates 2000). Hence, FTIR spectral analysis demonstrates the existence of negatively charged groups like $-\mathrm{CH}_{2},-\mathrm{OH},-\mathrm{Cl},-\mathrm{Br}$ on the surface of 
Fig. 2 FTIR spectrum of ASBR

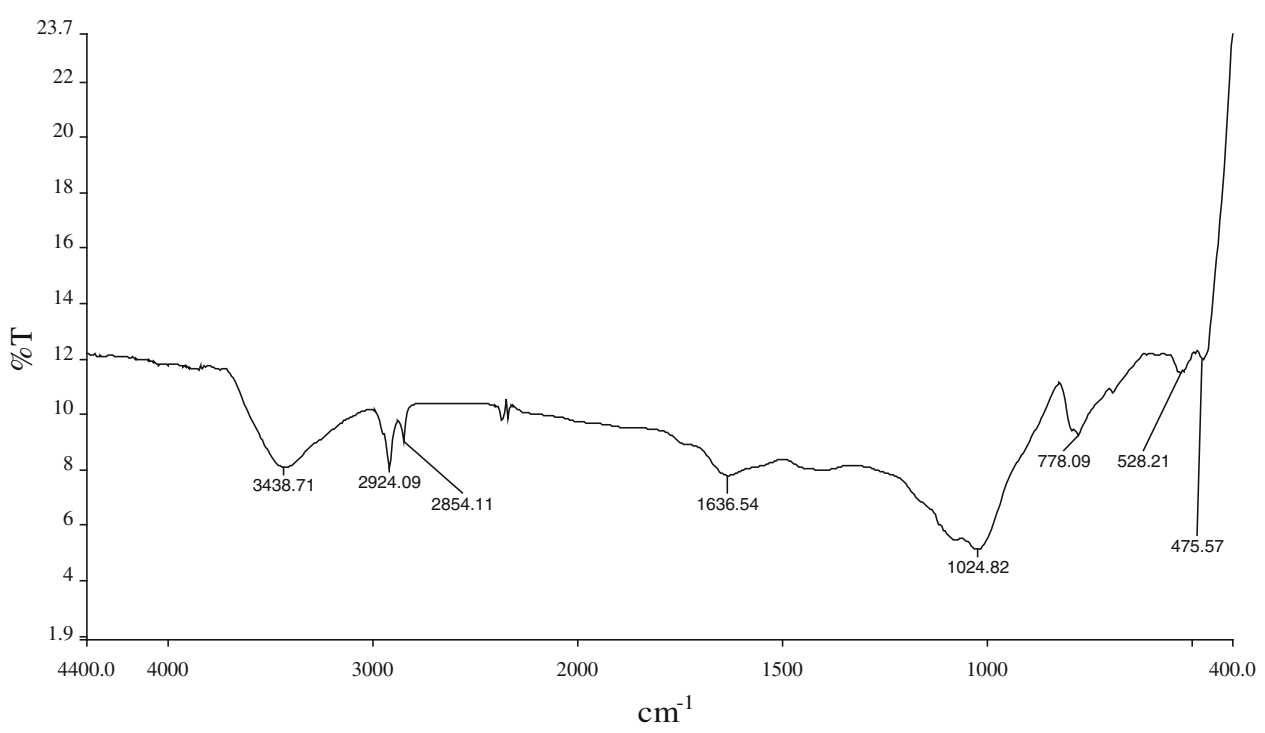

ASBR. X-ray diffraction spectrum of ASBR adsorbent is given in Fig. 3.

Scanning electron microscopy analysis is another useful tool for the analysis of the surface morphology of an adsorbent. The SEM images for ASBR surface before and after lead adsorption are shown in Figs. 4 and, 5 respectively. The porous and irregular surface structure of the adsorbent can be clearly observed in the SEM images shown in Fig. 4. After adsorption, the pores were filled by lead ions (Fig. 5).

\section{Effect of initial lead (II) ion concentration}

The rate of adsorption is a function of the initial concentration of the adsorbate, which makes it an important factor to be considered for effective adsorption. The effect of different initial lead (II) ion concentration on adsorption of lead (II) ion onto ASBR is presented in Fig. 6. The percentage removal of lead (II) ion decreased with increasing of the initial lead (II) ions concentration. This can be explained by the fact that all adsorbents have a limited number of active sites and at a certain concentration, the active sites become saturated (Tsai and Chen 2010). However, the adsorption capacity at equilibrium increased with increase in initial lead (II) ion concentration. It is possible that the initial concentration of the metal ions provides the necessary driving force to overcome the mass transfer resistance of lead ion between the aqueous and the solid phase (Chowdhury and Saha 2010). The increase in the initial lead ions concentration also enhances the interaction between the lead ions in the aqueous phase and the ASBR surface. Therefore, a higher initial concentration of lead ions enhances the rate of adsorption. Similar results were obtained in the adsorption of copper and lead ions by manganese oxide-coated sand (Han et al. 2006a, b).

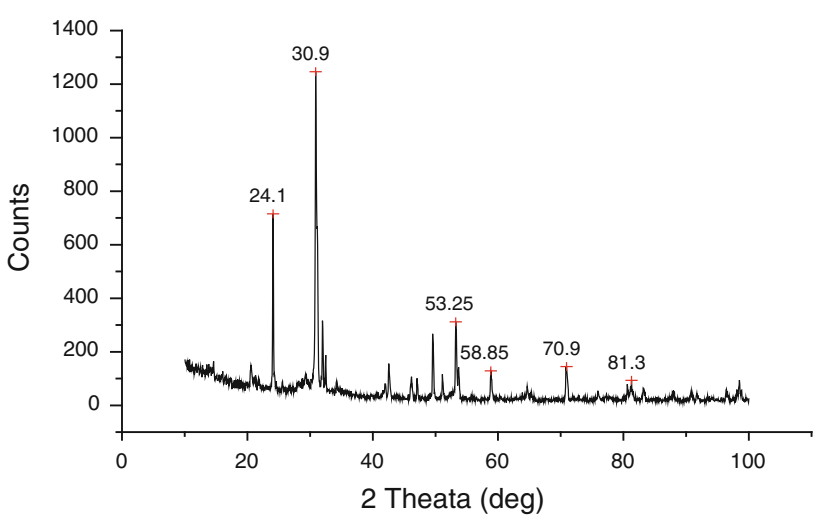

Fig. 3 XRD pattern of the adsorbent

\section{Effect of $\mathrm{pH}$}

The $\mathrm{pH}$ of the solution is one of the most critical parameters in the adsorption process, which affects surface charge of the adsorbent material and the degree of ionization and specification of adsorbate (Imamoglu and Tekir 2008). The effect of $\mathrm{pH}$ on the removal efficiency of lead (II) ion was studied at different $\mathrm{pH}$ values ranging from 2.0 to 8.0, the results are given in Fig. 7. It was observed that a sharp increase in the lead ion removal occurred when the $\mathrm{pH}$ value of the solutions changed from 2.0 to 6.0. The maximum adsorption of lead ions are obtained at $\mathrm{pH}$ 6.0. So $\mathrm{pH} 6.0$ was selected as optimum $\mathrm{pH}$ for lead ion adsorption onto ASBR. From pH 6 onwards, a steady decrease of adsorption of lead ions were recorded. Again, the FTIR spectral analysis indicates the presence of $-\mathrm{OH}$ functional group onto ASBR surface. This $-\mathrm{OH}$ group is protonated at lower $\mathrm{pH}$ and thereby restricts the approach of positively charged metal ions to the surface of the adsorbent which results in lower uptake of metal. With 


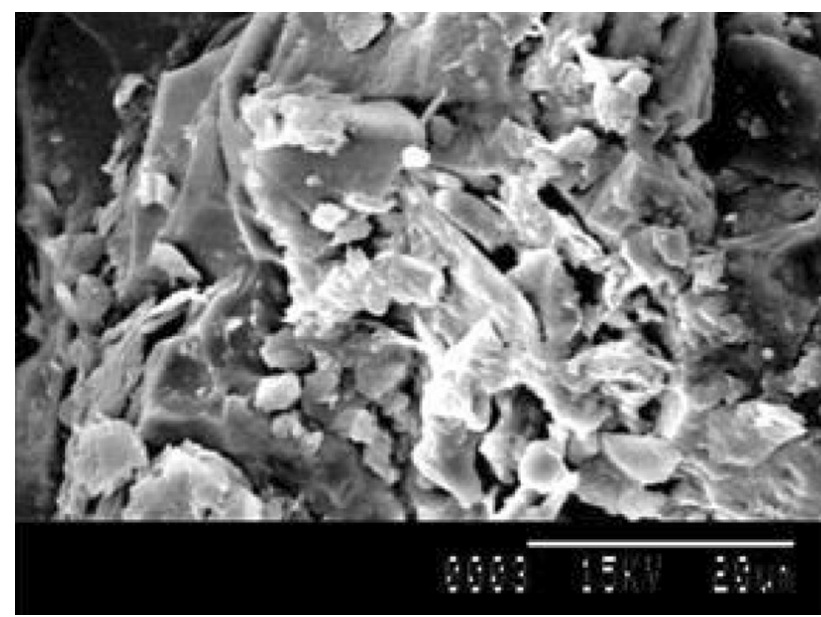

Fig. 4 SEM image of ASBR before adsorption

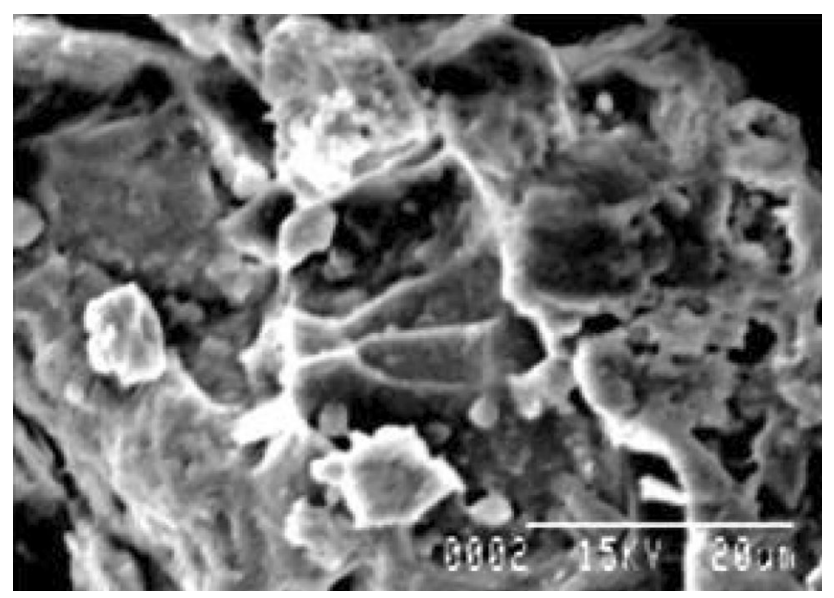

Fig. 5 SEM image of ASBR after adsorption

decrease in acidity of the solution, the functional group on the adsorbent surface becomes deprotonated resulting in an increase in the negative charge density on the adsorbent surface and facilitates the binding of metal cations. The increase in lead (II) ion removal efficiency at higher $\mathrm{pH}$ may also be attributed to the reduction of $\mathrm{H}^{+}$ions which compete with metal cations at lower pH (Ofomaja et al. 2010). Similar observation has been reported for sorption of lead onto Mansonia wood sawdust (Ofomaja et al. 2010).

\section{Effect of adsorbent dose}

In this study, five different adsorbent dosages were selected ranging from 0.5 to $2.5 \mathrm{~g}$, while the lead concentration was fixed at $25 \mathrm{mg} / \mathrm{L}$. The results are presented in Fig. 8. It was observed that percentage of lead ion removal increased with increase in adsorbent dose. Such a trend is mostly attributed to an increase in the sorptive surface area and the availability of more active binding sites on the surface of

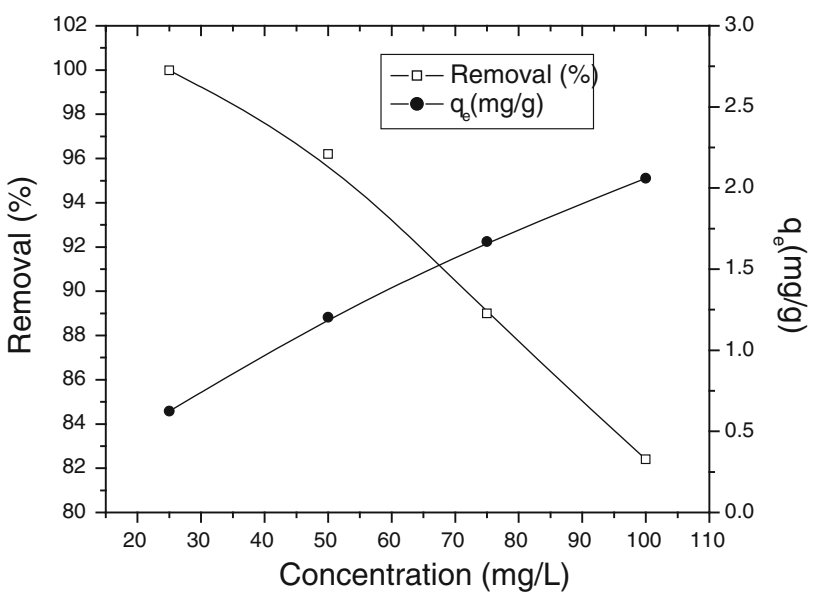

Fig. 6 Effect of initial concentration on lead adsorption (experimental conditions: adsorbent dose $2 \mathrm{~g} / 50 \mathrm{~mL}$, agitation speed $800 \mathrm{rpm}, \mathrm{pH} 6.0$, temperature $313 \mathrm{~K}$ contact time: $45 \mathrm{~min}$ )

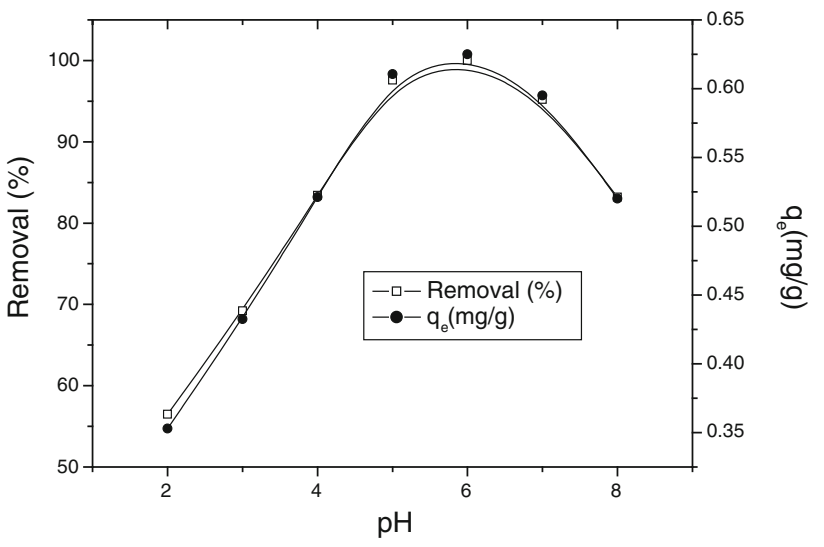

Fig. 7 Effect of $\mathrm{pH}$ on lead adsorption (experimental conditions: initial lead concentration $25 \mathrm{mg} / \mathrm{L}$, adsorbent dose $2 \mathrm{~g} / 50 \mathrm{~mL}$, agitation speed $800 \mathrm{rpm}$, temperature $313 \mathrm{~K}$, contact time $45 \mathrm{~min}$ )

the adsorbent (Abdel-Ghani et al. 2007). However, the equilibrium adsorption capacity showed an opposite trend. As the adsorbent dosage was increased from 0.5 to $2.5 \mathrm{~g}$, the adsorption capacity reduced to 1.81 and $0.5 \mathrm{mg} \mathrm{g}^{-1}$, respectively. This may be due to the decrease in total adsorption surface area available to lead ion resulting from overlapping or aggregation of adsorption sites (Crini et al. 2007; Akar et al. 2009). Thus, with increasing adsorbent mass, the amount of lead ion adsorbed onto unit mass of adsorbent gets reduced, thus, causing a decrease in $\mathrm{q}_{\mathrm{e}}$ value with increasing adsorbent mass concentration. Furthermore, maximum lead ion removal $(99.99 \%)$ was recorded by $2.0 \mathrm{~g} \mathrm{ASBR}$ and further increase in adsorbent dose did not significantly change the adsorption yield. This is due to the non-availability of active sites on the adsorbent and establishment of equilibrium between the lead ion on the adsorbent and in the solution. 


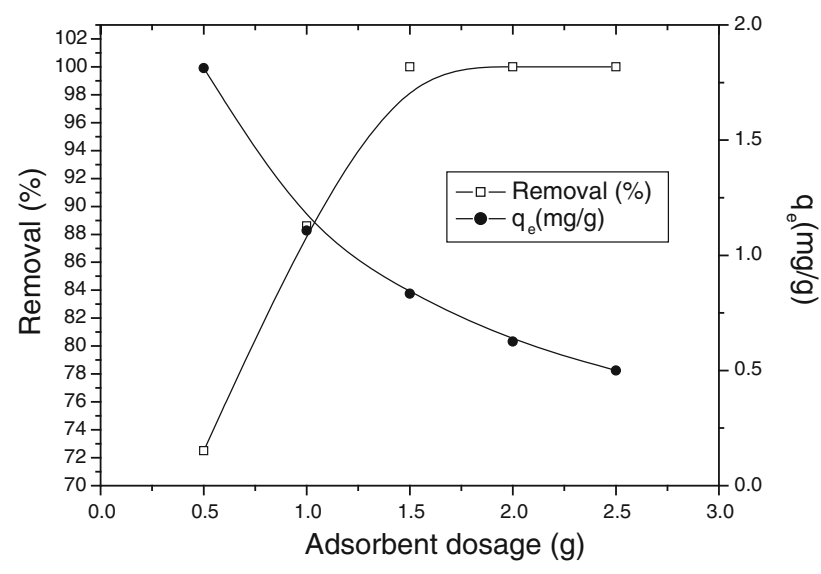

Fig. 8 Effect of adsorbent dose on lead adsorption (experimental conditions: initial lead concentration $25 \mathrm{mg} / \mathrm{L}$, agitation speed $800 \mathrm{rpm}, \mathrm{pH} 6.0$, temperature $313 \mathrm{~K}$, contact time $45 \mathrm{~min}$ )

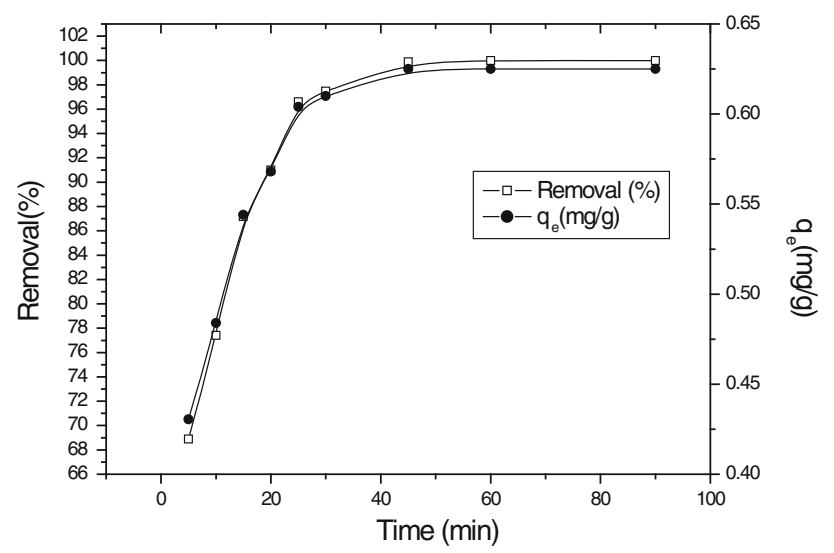

Fig. 9 Effect of contact time on lead adsorption (experimental conditions: initial lead concentration $25 \mathrm{mg} / \mathrm{L}$, adsorbent dose $2 \mathrm{~g} /$ $50 \mathrm{~mL}$, agitation speed $800 \mathrm{rpm}, \mathrm{pH} 6.0$, temperature $313 \mathrm{~K}$ )

\section{Effect of contact time}

The uptake of lead (II) ion as a function of contact time is shown in Fig. 9. The removal rate was rapid initially and then gradually decreases with time until it reaches equilibrium beyond which there was no significant increase in the rate of removal. The equilibrium nearly reached after 45 min for four different initial lead (II) ion concentrations. Hence, in the present work, 45 min was chosen as the equilibrium time. The fast adsorption rate at the initial stage may be explained by an increased availability in the number of active binding sites on the adsorbent surface. The sorption rapidly occurs and is normally controlled by the diffusion process from the bulk to the surface. In the later stage, the sorption is likely an attachment-controlled process due to less available sorption sites. Similar findings for lead (II) adsorption onto other adsorbents have been

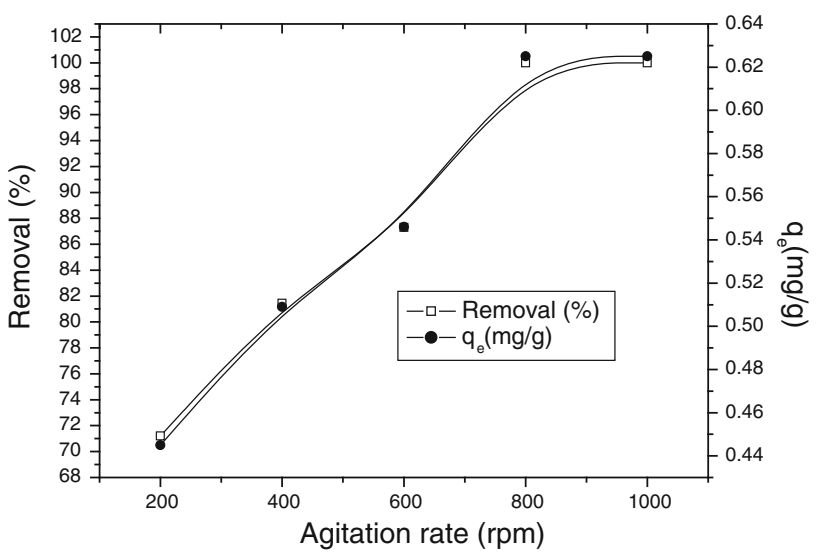

Fig. 10 Effect of shaking rate on lead adsorption (experimental conditions: initial lead concentration $25 \mathrm{mg} / \mathrm{L}$, adsorbent dose $2 \mathrm{~g} /$ $50 \mathrm{~mL}$, pH: 6.0, Contact time: $45 \mathrm{~min}$, Temperature: $313 \mathrm{~K}$ )

reported by other investigators (Kannan and Veemaraj 2009; Badmus et al. 2007).

\section{Effect of stirring rate}

The effect of stirring rate on lead adsorption is shown in Fig. 10 and it appears that stirring rate has pronounced an effect on the amount of lead adsorbed. As the stirring rate increased from 200 to $1,000 \mathrm{rpm}$, the adsorption capacity increased from 0.445 to $0.625 \mathrm{mg} \mathrm{g}^{-1}$. However, beyond $800 \mathrm{rpm}$, the adsorption capacity remained constant and the stirring rate of $800 \mathrm{rpm}$ was selected in subsequent analysis. The increase in adsorption capacity at a higher stirring rate could be explained in terms of the reduction of boundary layer thickness around the adsorbent particles (Hanafiah et al. 2009). Therefore, with increasing stirring rate, the concentrations of lead ions near the adsorbent surface would be increased. A higher stirring rate also encouraged a better mass transfer of lead ions from bulk solution to the surface of the adsorbent and shortened the adsorption equilibrium time.

\section{Adsorption isotherms}

An adsorption isotherm represents the equilibrium relationship between the adsorbate concentration in the liquid phase and that on the adsorbent surface at a given condition. A number of isotherms have been developed to describe equilibrium relationships. In the present study, Langmuir, Freundlich, Temkin, and Dubinin-Radushkevich (D-R) models were used to describe the equilibrium data. The results are shown in Table 2 and the modeled isotherms are plotted in Fig. 11. 
Table 2 Adsorption isotherm constants for adsorption of lead (II) onto ASBR

\begin{tabular}{|c|c|c|c|c|c|c|}
\hline Adsorption isotherms & Parameters & & $R^{2}$ & $\chi^{2}$ & SSE & $\overline{\text { SAE }}$ \\
\hline \multirow[t]{2}{*}{ Langmuir isotherm } & $q_{\max }(\mathrm{mg} / \mathrm{g})$ & 1.567 & 0.918 & 0.251 & 0.39 & 1.023 \\
\hline & $k_{\mathrm{L}}(\mathrm{L} / \mathrm{mg})$ & 319.08 & & & & \\
\hline \multirow[t]{2}{*}{ Freundlich isotherm } & $K_{\mathrm{F}}(\mathrm{mg} / \mathrm{g})\left(\mathrm{L} \mathrm{mg}^{-1}\right)^{1 / n}$ & 1.28 & 0.957 & 0.051 & 0.084 & 0.432 \\
\hline & $N$ & 7.93 & & & & \\
\hline \multirow[t]{2}{*}{ Temkin isotherm } & $B(\mathrm{mg} / \mathrm{g})$ & 0.142 & 0.865 & 0.1 & 0.154 & 0.648 \\
\hline & $A$ & $19.3 \times 10^{3}$ & & & & \\
\hline \multirow[t]{3}{*}{$\mathrm{D}-\mathrm{R}$ isotherm } & $q_{\mathrm{m}}(\mathrm{mg} / \mathrm{g})$ & 1.606 & 0.822 & 2.39 & 7.52 & 3.601 \\
\hline & $\beta\left(\mathrm{mol}^{2} \mathrm{~kJ}^{-2}\right)$ & 0.003 & & & & \\
\hline & $E\left(\mathrm{~kJ} \mathrm{~mol}^{-1}\right)$ & 12.90 & & & & \\
\hline
\end{tabular}

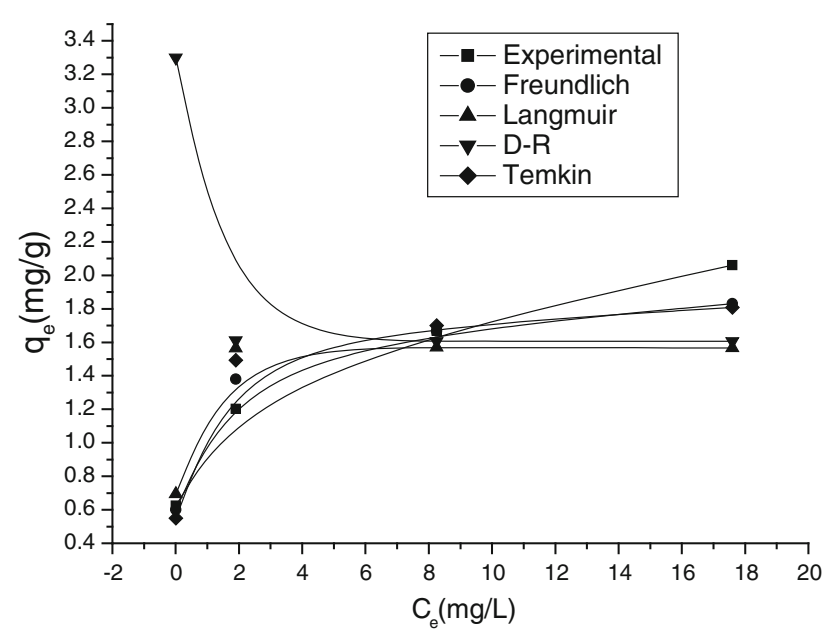

Fig. 11 Comparison between the measured and modeled isotherm profiles for the adsorption of lead ions by ASBR (experimental conditions: adsorbent dose $2.0 \mathrm{~g} / 50 \mathrm{~mL}$, agitation speed $800 \mathrm{rpm}, \mathrm{pH}$ 6.0 , contact time $45 \mathrm{~min}$, temperature $313 \mathrm{~K}$ )

The Langmuir isotherm model

The Langmuir isotherm model (Langmuir, 1918) was used to describe observed sorption phenomena and suggests that uptake occurs on a homogeneous surface by monolayer sorption without interaction between adsorbed molecules. The linear form of the equation can be written as:

$\frac{1}{q_{\mathrm{eq}}}=\frac{1}{q_{\max } k_{\mathrm{L}} C_{\mathrm{e}}}+\frac{1}{q_{\max }}$

where $C_{\mathrm{e}}$ is the equilibrium concentration of $\mathrm{Pb}$ (II) in (mg/ $\mathrm{L}), q_{\mathrm{eq}}$ is the amount of metal adsorbed per specific amount of adsorbent $(\mathrm{mg} / \mathrm{g}), q_{\max }$ is the maximum adsorption capacity $(\mathrm{mg} / \mathrm{g})$, and $k_{\mathrm{L}}$ is an equilibrium constant $(\mathrm{L} / \mathrm{mg})$ related to energy of adsorption which quantitatively reflects the affinity between the adsorbent and adsorbate. Where $q_{\max }$ and $k_{\mathrm{L}}$ can be determined from the linear plot of $1 / q_{\mathrm{eq}}$ versus $1 / C_{\mathrm{e}}$. The shape of the Langmuir isotherm can be used to predict whether a sorption system is favorable or unfavorable in a batch adsorption process. The essential features of the isotherm can be expressed in terms of a dimensionless constant separation factor $\left(R_{\mathrm{L}}\right)$ that can be defined by the following relationship (Anirudhan and Radhakrishnan 2008).

$R_{\mathrm{L}}=\frac{1}{1+k_{\mathrm{L}} C_{\mathrm{i}}}$

where $C_{\mathrm{i}}$ is the initial concentration $(\mathrm{mg} / \mathrm{L})$ and $k_{\mathrm{L}}$ is the Langmuir equilibrium constant $(\mathrm{L} / \mathrm{mg})$. The value of separation parameter $R_{\mathrm{L}}$ provides important information about the nature of adsorption. The value of $R_{\mathrm{L}}$ indicated the type of Langmuir isotherm to be irreversible $\left(R_{\mathrm{L}}=0\right)$, favorable $\left(0<R_{\mathrm{L}}<1\right)$, linear $\left(R_{\mathrm{L}}=1\right)$ or unfavorable $\left(R_{\mathrm{L}}>1\right)$. It can be explained apparently that when $k_{\mathrm{L}}>0$, sorption system is favorable (Chen et al. 2008). The evaluated constants are given in Table 2 .

The Freundlich isotherm model

The Freundlich isotherm is applicable to non-ideal adsorption on heterogeneous surfaces and the linear form of the isotherm can be represented as (Freundlich 1906):

$\log q_{\mathrm{eq}}=\log K_{\mathrm{F}}+\frac{1}{n} \log C_{\mathrm{e}}$

where $K_{\mathrm{F}}$ is the Freundlich constant related to sorption capacity in $(\mathrm{mg} / \mathrm{g})(\mathrm{L} / \mathrm{g})^{1 / n}$ and $n$ is related to the adsorption intensity of the adsorbent. Where, $K_{\mathrm{F}}$ and $1 / n$ can be determined from the linear plot of $\log q_{\mathrm{eq}}$ versus $\log C_{\mathrm{e}}$. The evaluated constants are given in Table 2 .

The Temkin isotherm model

Unlike the Langmuir and Freundlich equation, the Temkin isotherm takes into account the interactions between adsorbents and metal ions to be adsorbed and is based on the assumption that the free energy of sorption is a function of the surface coverage (Chen et al. 2008). The linear form of the Temkin isotherm is represented as: 
$q_{\mathrm{e}}=B \ln A+B \ln C_{\mathrm{e}}$

where $C_{\mathrm{e}}$ is concentration of the adsorbate at equilibrium $(\mathrm{mg} / \mathrm{L}), q_{\mathrm{e}}$ is the amount of adsorbate adsorbed at equilibrium $(\mathrm{mg} / \mathrm{g}), R T / b_{\mathrm{T}}=B$ where $T$ is the temperature $(\mathrm{K})$, and $R$ is the ideal gas constant $\left(8.314 \mathrm{~J} \mathrm{~mol}^{-1} \mathrm{~K}^{-1}\right)$ and $A$ and $b_{\mathrm{T}}$ are constants. A plot of $q_{\mathrm{e}}$ versus $\ln C_{\mathrm{e}}$ enables the determination of constants $A$ and $B$. The constant $B$ is related to the heat of adsorption and $A$ is the equilibrium binding constant $(\mathrm{L} / \mathrm{min})$ corresponding to the maximum binding energy. The values of $A$ and $B$ are given in Table 2 .

\section{The Dubinin-Radushkevich isotherm model}

The Dubinin-Radushkevich model (Dubinin et al. 1947) was chosen to estimate the heterogeneity of the surface energies. The linear form of $\mathrm{D}-\mathrm{R}$ isotherm equation is represented as:

$\ln q_{\mathrm{e}}=\ln q_{\mathrm{m}}-\beta \epsilon^{2}$

where

$\in=R T \ln \left(1+\frac{1}{C_{\mathrm{e}}}\right)$

where $q_{\mathrm{m}}$ is the theoretical saturation capacity ( $\mathrm{mol} / \mathrm{g}$ ), $\beta$ is a constant related to the mean free energy of adsorption per mole of the adsorbate $\left(\mathrm{mol}^{2} / \mathrm{J}^{2}\right)$, and $\varepsilon$ is the polanyi potential, $C_{\mathrm{e}}$ is the equilibrium concentration of adsorbate in solution $(\mathrm{mol} / \mathrm{L}), R\left(8.314 \mathrm{~J} \mathrm{~mol}^{-1} \mathrm{~K}^{-1}\right)$ is the gas constant, and $T(\mathrm{~K})$ is the absolute temperature. The $\mathrm{D}-\mathrm{R}$ constants $q_{\mathrm{m}}$ and $\beta$ were calculated from the linear plots of $\ln q_{\mathrm{e}}$ versus $\varepsilon^{2}$ and are given in Table 2. The constant $\beta$ gives an idea about the mean free energy $E(\mathrm{~kJ} / \mathrm{mol})$ of adsorption per molecule of the adsorbate when it is transferred to the surface of the solid from infinity in the solution and can be calculated from the relationship (Kundu and Gupta 2006)

$E=\frac{1}{\sqrt{2 \beta}}$

If the magnitude of $E$ is between 8 and $16 \mathrm{~kJ} \mathrm{~mol}^{-1}$, the sorption process is supposed to proceed via chemisorption, while for values of $E<8 \mathrm{~kJ} \mathrm{~mol}^{-1}$, the sorption process is of physical nature (Kundu and Gupta 2006).

\section{Error analysis}

Due to the inherent bias resulting from linearization, three different error functions of non-linear regression basin [sum of the square of the errors (SSE), sum of the absolute errors (SAE), and Chi square $\left.\left(\chi^{2}\right)\right]$ were employed in this study to find out the best-fit isotherm model to the experimental equilibrium data.
SSE is given as:

$\mathrm{SSE}=\sum_{i=1}^{n}\left(q_{\mathrm{e}, \mathrm{estm}}-q_{\mathrm{e}, \mathrm{exp}}\right)_{i}^{2}$

Here, $q_{\mathrm{e}, \mathrm{estm}}$ and $q_{\mathrm{e}, \mathrm{exp}}$ are, respectively, the estimated and the experimental value of the equilibrium adsorbate solid concentration in the solid phase $(\mathrm{mg} / \mathrm{g})$, and $\mathrm{n}$ is the number of the data point.

SAE is given as:

$\mathrm{SAE}=\sum_{i=1}^{n} q_{\mathrm{e}, \mathrm{estm}}-q_{\mathrm{e}, \exp _{i}}$

Chi square $\left(\chi^{2}\right)$ is given as:

$\chi^{2}=\sum_{i=1}^{n}\left[\frac{\left(q_{\mathrm{e}, \mathrm{exp}}-q_{\mathrm{e}, \mathrm{estm}}\right)^{2}}{q_{\mathrm{e}, \mathrm{estm}}}\right]_{i}$

The respective values are given in the Table 2 .

As shown in Table 2, the Freundlich isotherm showed good fit to the experimental equilibrium adsorption data than the Langmuir, Dubinin-Radushkevich, and Tempkin isotherm equation for $\mathrm{Pb}$ (II) sorption according to the values of $R^{2}, \chi^{2}$, SSE, and SAE. It was also seen from Table 2 that the Langmuir maximum adsorption capacity $\left(q_{\max }\right)$ is $1.567 \mathrm{mg} / \mathrm{g}$ and the equilibrium constant $k_{\mathrm{L}}$ is $319.08 \mathrm{~L} / \mathrm{mg}$. The separation factor $\left(R_{\mathrm{L}}\right)$ values are $1.25 \times 10^{-4}, 6.26 \times 10^{-5}, 4.17 \times 10^{-5}$, and $3.13 \times 10^{-5}$ while initial $\mathrm{Pb}(\mathrm{II})$ concentrations are $25,50,75$, and $100 \mathrm{mg} / \mathrm{L}$, respectively. All the $R_{\mathrm{L}}$ values were found to be less than one and greater than zero indicating the favorable sorption of $\mathrm{Pb}(\mathrm{II})$ onto ASBR. The Freundlich constant $K_{\mathrm{F}}$ indicates the sorption capacity of the sorbent and the value of $K_{\mathrm{F}}$ is $1.28 \mathrm{mg} / \mathrm{g}$. Furthermore, the value of ' $n$ ' at equilibrium was 7.93. The value of $n$ between 1 and 10 represents a favorable adsorption (Slejko 1985). From D-R isotherm, the value of the adsorption energy was found to be $12.90 \mathrm{~kJ} / \mathrm{mol}$. The estimated value of $E$ for the present study was found in the range expected for chemical adsorption (Table 2). Thus, the sorption of $\mathrm{Pb}(\mathrm{II})$ on the surface of ASBR was chemical in nature.

The effectiveness of ASBR as an adsorbent for lead adsorption was also compared with other reported adsorbents. The maximum adsorption capacity obtained in this study is comparable with other adsorbents as shown in Table 3.

\section{Adsorption kinetics modeling}

To analyze the rate of adsorption and possible adsorption mechanism of lead onto ASBR, the Lagergren first-order (Lagergren 1898), pseudo second-order (Ho and Mckay 2000), intra-particle diffusion (Weber and Morris 1963), and surface mass transfer models (Mckay et al. 1981) were applied to adsorption data. 
Table 3 A comparisons of maximum adsorption capacities for lead ions by different adsorbents

\begin{tabular}{lll}
\hline Adsorbents & $\begin{array}{l}q_{\max }(\mathrm{mg} / \\
\mathrm{g})\end{array}$ & References \\
\hline Activated carbon & 6.68 & Mishra and Patel (2009) \\
Kaolin & 4.50 & Mishra and Patel (2009) \\
Saraca indica leaf powder & 1.19 & Goyal et al. (2008) \\
Rolling mill scale & 2.74 & Martin et al. (2005) \\
$\begin{array}{l}\text { Bagasse flyash } \\
\text { Periwinkle shell carbon }\end{array}$ & 2.50 & Gupta and Ali (2004) \\
$\begin{array}{l}\text { Tea waste } \\
\text { Manganese oxide-coated }\end{array}$ & 2.0558 & $\begin{array}{l}\text { Badmus et al. (2007) } \\
\text { zeolite }\end{array}$ \\
$\begin{array}{lll}\text { ASBR } & 1.117 & \text { Ahluwalia and Goyal } \\
\text { (2005) }\end{array}$ \\
\hline
\end{tabular}

The pseudo first-order kinetic model

The Lagergren first-order rate equation is represented as:

$\log \left(q_{\mathrm{e}}-q_{\mathrm{t}}\right)=\log q_{\mathrm{e}}-\frac{k_{1} t}{2.303}$

where $q_{\mathrm{e}}$ and $q_{\mathrm{t}}$ are the amounts of lead adsorbed (mg/g) at equilibrium and at time $t$, respectively, and $k_{1}$ is the Lagergren rate constant of first-order adsorption $\left(\mathrm{min}^{-1}\right)$. Values of $q_{\mathrm{e}}$ and $k_{1}$ at different concentrations were calculated from the slope and intercept of the plots of $\log \left(q_{\mathrm{e}}\right.$ $-q_{\mathrm{t}}$ ) versus $\mathrm{t}$ (Fig. 12). The respective values are given in the Table 4 .

The pseudo second-order kinetic model

The pseudo second-order kinetic model, which is based on the assumption that chemisorption is the rate-determining step can be expressed as:

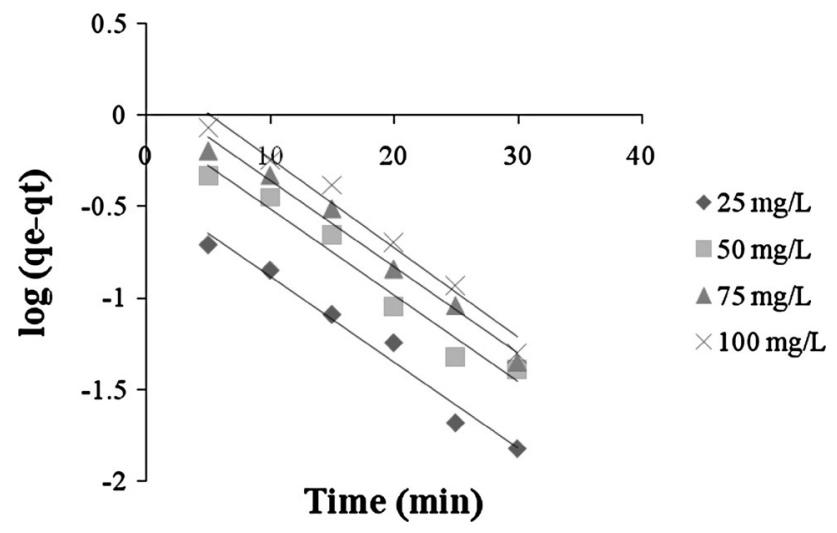

Fig. 12 Pseudo first-order kinetic plots for adsorption of lead onto ASBR (experimental conditions: adsorbent dose $2 \mathrm{~g} / 50 \mathrm{~mL}$, agitation speed $800 \mathrm{rpm}, \mathrm{pH} 6.0$, temperature $313 \mathrm{~K}$ ) $\frac{t}{q_{\mathrm{t}}}=\frac{1}{k_{2} q_{\mathrm{e}}^{2}}+\frac{t}{q_{\mathrm{e}}}$

where $k_{2}$ is the rate constant of second-order adsorption (g/ $\mathrm{mg} / \mathrm{min}$ ). Values of $k_{2}$ and $q_{\mathrm{e}}$ were calculated from the plots of $t / q_{\mathrm{t}}$ versus $t$ (Fig. 13). The respective constant values are given in Table 4. Furthermore, the plot of $t / q_{\mathrm{t}}$ versus $t$ at different temperatures is shown in Fig. 14, and the pseudo second-order model constants at different temperatures were presented in the Table 5. The initial adsorption rate, $h\left(\mathrm{mg} \mathrm{g}^{-1} \mathrm{~min}^{-1}\right)$ at different temperatures was calculated using Eq. 16 (Sari et al. 2010) from the pseudo second-order kinetic parameters and are presented in Table 5.

$h=k_{2} q_{\mathrm{e}}^{2}$

The intra-particle diffusion model

The kinetic results were analyzed by the Weber and Morris intra-particle diffusion model to elucidate the diffusion mechanism. The model is expressed as:

$q_{\mathrm{t}}=K_{\mathrm{d}} t^{1 / 2}+I$

where $I$ is the intercept and $K_{\mathrm{d}}$ is the intra-particle diffusion rate constant. The intercept of the plot reflects the boundary layer effect. Larger the intercept, greater is the contribution of the surface sorption in the rate-controlling step. Figure 15 presents the intra-particle plot for $\mathrm{Pb}(\mathrm{II})$ onto ASBR. The calculated diffusion coefficient $K_{\mathrm{d}}$ values are listed in Table 4 . The $k_{\text {id }}$ value was higher at the higher concentrations. Intra-particle diffusion is the sole ratelimiting step if the regression of $q_{\mathrm{t}}$ versus $t^{1 / 2}$ is linear and passes through the origin. In fact, the linear plots at each concentration did not pass through the origin. This deviation from the origin is due to the difference in the rate of mass transfer in the initial and final stages of the sorption. This indicated the existence of some boundary layer effect, and further showed that intra-particle diffusion was not the only rate-limiting step.

Surface mass transfer kinetic model

Mass transfer analysis for the removal of lead was carried out using the kinetic model which describes the transfer of adsorbate in solution. The model is expressed as:

$\ln \left(\frac{C_{\mathrm{t}}}{C_{0}}-\frac{1}{1+m k_{\mathrm{L}}}\right)=\ln \frac{m k_{\mathrm{L}}}{1+m k_{\mathrm{L}}}-\frac{1+m k_{\mathrm{L}}}{m k_{\mathrm{L}}} \beta_{\mathrm{L}} S_{\mathrm{s}} t$

where $C_{\mathrm{t}}$ is the concentration $(\mathrm{mg} / \mathrm{L})$ after time $t, C_{0}$ is the initial concentration $(\mathrm{mg} / \mathrm{L}), m$ is the mass of adsorbent per unit volume of particle-free adsorbate solution $(\mathrm{g} / \mathrm{L}), \beta_{\mathrm{L}}$ is the mass transfer coefficient $(\mathrm{cm} / \mathrm{s}), k_{\mathrm{L}}$ is the constant obtained from the Langmuir isotherm equation in $\mathrm{L} / \mathrm{g}$, and 
Table 4 Kinetic parameters for adsorption of lead (II) onto ASBR

\begin{tabular}{|c|c|c|c|c|c|}
\hline \multirow[t]{2}{*}{ Kinetic model } & \multirow[t]{2}{*}{ Parameters } & \multicolumn{4}{|c|}{ Concentration of lead (II) solution } \\
\hline & & $25 \mathrm{mg} / \mathrm{L}$ & $50 \mathrm{mg} / \mathrm{L}$ & $75 \mathrm{mg} / \mathrm{L}$ & $100 \mathrm{mg} / \mathrm{L}$ \\
\hline \multirow[t]{4}{*}{ Pseudo first-order } & $q_{\mathrm{e}, \exp }(\mathrm{mg} / \mathrm{g})$ & 0.625 & 1.202 & 1.669 & 2.060 \\
\hline & $k_{1}\left(\min ^{-1}\right)$ & 0.106 & 0.108 & 0.109 & 0.110 \\
\hline & $q_{\mathrm{e}, \mathrm{cal}}(\mathrm{mg} / \mathrm{g})$ & 0.386 & 0.918 & 1.294 & 1.786 \\
\hline & $R^{2}$ & 0.973 & 0.966 & 0.983 & 0.976 \\
\hline \multirow[t]{3}{*}{ Pseudo second-order } & $k_{2}\left(\mathrm{~g} / \mathrm{mg}^{-1} \min ^{-1}\right)$ & 0.624 & 0.230 & 0.171 & 0.130 \\
\hline & $q_{\mathrm{e}, \mathrm{cal}}(\mathrm{mg} / \mathrm{g})$ & 0.647 & 1.262 & 1.751 & 2.173 \\
\hline & $R^{2}$ & 0.999 & 0.998 & 0.998 & 0.998 \\
\hline \multirow[t]{3}{*}{ Intra-particle diffusion } & $K_{\mathrm{d}}\left(\mathrm{mg} / \mathrm{g} \min ^{1 / 2}\right)$ & 0.025 & 0.063 & 0.085 & 0.112 \\
\hline & $I$ & 0.430 & 0.777 & 1.021 & 1.212 \\
\hline & $R^{2}$ & 0.714 & 0.333 & 0.717 & 0.714 \\
\hline \multirow[t]{2}{*}{ Surface mass transfer } & $\beta_{\mathrm{L}}(\mathrm{cm} / \mathrm{s})$ & $2.14 \times 10^{-5}$ & $0.146 \times 10^{-5}$ & $0.086 \times 10^{-5}$ & $0.071 \times 10^{-5}$ \\
\hline & $R^{2}$ & 0.915 & 0.854 & 0.806 & 0.776 \\
\hline
\end{tabular}

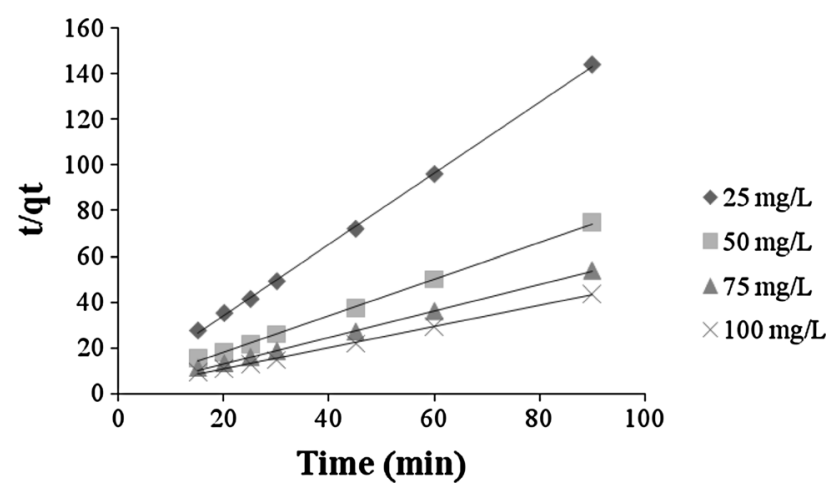

Fig. 13 Pseudo second-order kinetic plots for adsorption of lead onto ASBR (experimental conditions: adsorbent dose $2 \mathrm{~g} / 50 \mathrm{~mL}$, agitation speed $800 \mathrm{rpm}, \mathrm{pH} 6.0$, temperature $313 \mathrm{~K}$ )

$S_{\mathrm{s}}$ is the outer surface of adsorbent per unit volume of particle-free solution in $\mathrm{cm}^{-1}$, given as:

$S_{\mathrm{s}}=\frac{6 \mathrm{~m}}{D_{\mathrm{a}} d(1-\varepsilon)}$

where $D_{\mathrm{a}}$ is the particle mean diameter $(\mathrm{cm}), d$ is the density of the adsorbent $\left(\mathrm{g} / \mathrm{cm}^{3}\right)$, and $\varepsilon$ is the porosity of the adsorbent. The results are showing in Fig. 16. The plot of $\ln \left(\frac{C_{\mathrm{t}}}{C_{0}}-\frac{1}{1+m k_{\mathrm{L}}}\right)$ versus $\mathrm{t}$ for gives a straight line, and thus, confirms the validity of the equation for the present system. The value of $\beta_{\mathrm{L}}$ for different initial concentrations was determined from the slope and intercept of the plots and are shown in Table 4.

It is clear from the Table 4 that the pseudo second-order kinetic model showed excellent linearity with high correlation coefficient $\left(R^{2}>0.99\right)$ at all the studied concentrations in comparison to the other kinetic models. In addition, the calculated $q_{\mathrm{e}}$ values also agree with the experimental data in the case of pseudo second-order kinetic model.

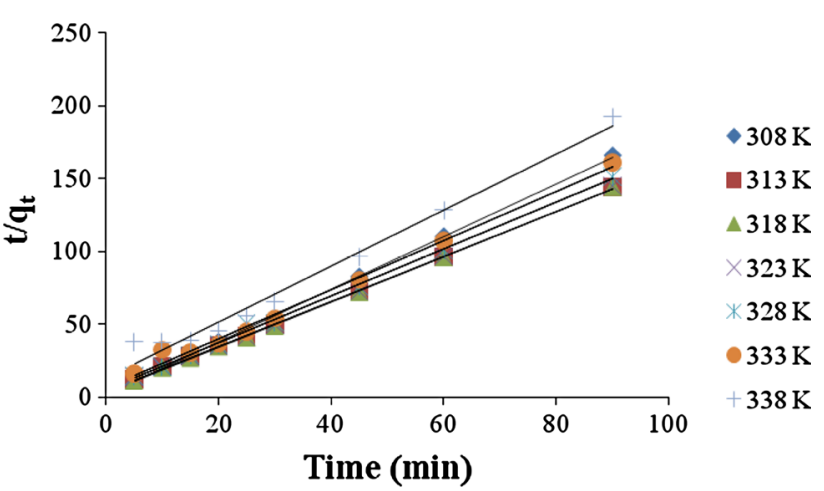

Fig. 14 Pseudo second- order kinetic plots for adsorption of lead onto ASBR at different temperatures (experimental conditions: initial concentration $25 \mathrm{mg} / \mathrm{L}$, adsorbent dose $2 \mathrm{~g} / 50 \mathrm{~mL}$, agitation speed $800 \mathrm{rpm}, \mathrm{pH}$ 6.0)

Table 5 Pseudo second-order kinetic parameters at different temperatures

\begin{tabular}{llll}
\hline$T(\mathrm{~K})$ & $q_{\mathrm{e}, \mathrm{cal}}\left(\mathrm{mg} \mathrm{g}^{-1}\right)$ & $k_{2}\left(\mathrm{~g} \mathrm{mg}^{-1} \mathrm{~min}^{-1}\right)$ & $H\left(\mathrm{mg} \mathrm{g}^{-1} \mathrm{~min}^{-1}\right)$ \\
\hline 308 & 0.554 & 1.54 & 0.455 \\
313 & 0.647 & 0.624 & 0.261 \\
318 & 0.645 & 0.615 & 0.255 \\
323 & 0.648 & 0.548 & 0.23 \\
328 & 0.623 & 0.478 & 0.185 \\
333 & 0.593 & 0.44 & 0.154 \\
338 & 0.521 & 0.27 & 0.073 \\
\hline
\end{tabular}

Therefore, it could be concluded that the rate-limiting step of $\mathrm{Pb}$ (II) adsorption onto ASBR may be chemisorption. It is also evident from Table 4 that the values of the rate constant $k_{2}$ decrease with increasing initial $\mathrm{Pb}$ (II) concentrations. This is due to the lower competition for the surface active sites at lower concentration, but at higher 


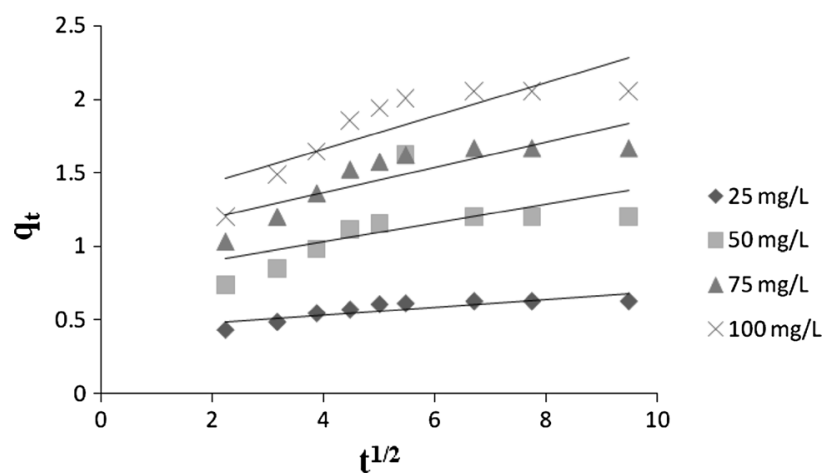

Fig. 15 Intra-particle diffusion model for adsorption of lead onto ASBR (experimental conditions: adsorbent dose $2 \mathrm{~g} / 50 \mathrm{~mL}$, agitation speed $800 \mathrm{rpm}, \mathrm{pH} 6.0$, temperature $313 \mathrm{~K}$ )

concentration the competition for the surface active sites will be high and consequently, lower sorption rates are obtained. It is also observed from Table 5 that rate constant, $k_{2}$ decreased as the temperature increased indicating the exothermic nature of adsorption of lead ion onto ASBR. Again as evident from Table 5, the initial adsorption rate, $h$, decreased with increase in temperature suggesting that adsorption of lead ion onto ASBR was not favorable at higher temperatures. Again as shown in Table 4, the external mass transfer coefficient ranges from $2.14 \times 10^{-5}$ $\mathrm{cm} / \mathrm{s}$ for $25 \mathrm{mg} / \mathrm{L}$ initial $\mathrm{Pb}(\mathrm{II})$ and $0.071 \times 10^{-5} \mathrm{~cm} \mathrm{~s}^{-1}$ for $100 \mathrm{mg} / \mathrm{L} \mathrm{Pb}$ (II) concentration. It was found that the external mass transfer coefficient decreased with increase in initial $\mathrm{Pb}$ (II) concentration. These results are consistent with previous studies on copper and mercury sorption onto chitosan (Mckay et al. 1986).

Activation energy and thermodynamic parameters

To study the feasibility of the adsorption process, the thermodynamic parameters such as free energy, enthalpy and entropy changes can be estimated from the following equations (Senthilkumar et al. 2011):

$K_{\mathrm{C}}=\frac{C_{\mathrm{Ae}}}{C_{\mathrm{e}}}$

$\Delta \mathrm{G}^{0}=-R T \ln K_{\mathrm{C}}$

$\log K_{\mathrm{C}}=\frac{\Delta S^{0}}{2.303 R}-\frac{\Delta H^{0}}{2.303 R T}$

where $C_{\mathrm{e}}$ is the equilibrium concentration in solution in $\mathrm{mg} / \mathrm{L}$ and $C_{\mathrm{Ae}}$ is the equilibrium concentration on the sorbent in $\mathrm{mg} / \mathrm{L}$ and $K_{\mathrm{c}}$ is the equilibrium constant. The Gibbs free energy $\left(\Delta G^{0}\right)$ for the adsorption of lead onto ASBR at all temperatures was obtained from Eq. 21 and is presented in Table 6. The values of $\Delta H^{0}$ and $\Delta S^{0}$ were calculated from the slope and intercept of the plot $\log K_{\mathrm{c}}$ against 1/T (Fig. not shown) and are listed in Table 6.

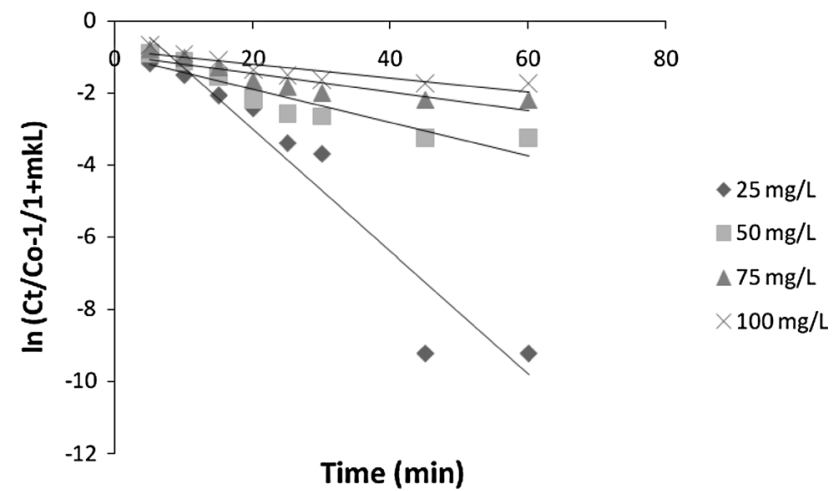

Fig. 16 Mass transfer plot for the adsorption of lead on ASBR (experimental conditions: initial lead ion concentration $25 \mathrm{mg} \mathrm{L}^{-1}$, adsorbent dose $2 \mathrm{~g} / 50 \mathrm{~mL}$, agitation speed $800 \mathrm{rpm}, \mathrm{pH}$ 6.0, temperature $313 \mathrm{~K}$ )

From the pseudo second-order rate constant $k_{2}$ (Table 5), the activation energy $E_{\mathrm{a}}$ for the adsorption of lead ions on ASBR was determined using the Arrhenius equation

$\ln k=\ln A-\frac{E_{\mathrm{a}}}{R T}$

where $k$ is the rate constant, $A$ is the Arrhenius constant, $E_{\mathrm{a}}$ is the activation energy $\left(\mathrm{kJ} \mathrm{mol}^{-1}\right), R$ is the gas constant $\left(8.314 \mathrm{~J} \mathrm{~mol}^{-1} \mathrm{~K}^{-1}\right)$, and $T$ is the temperature $(\mathrm{K})$. By plotting $\ln k_{2}$ versus $1 / T, E_{\mathrm{a}}$ was obtained from the slope of the linear plot (Fig. 17) and is presented in Table 6.

From Table 6 it is clear that the reaction is spontaneous in nature as $\Delta G^{0}$ values are negative at all the temperature studied. Increase in value of $\Delta G^{0}$ with increase in temperature suggests that lower temperature makes the adsorption easier. Again negative $\Delta H^{0}$ value confirms that the sorption is exothermic in nature. The type of sorption can be explained in terms of the magnitude of $\Delta H^{0}$. The heat evolved during physisorption generally lies in the range of 2.1-20.9 $\mathrm{kJ} \mathrm{mol}^{-1}$, while the heats of chemisorption falls into a range of $80-200 \mathrm{~kJ} \mathrm{~mol}^{-1}$ (Liu and Liu

Table 6 Thermodynamic parameters for adsorption of lead (II) onto ASBR

\begin{tabular}{lllll}
\hline $\begin{array}{l}\text { Temperature } \\
(\mathrm{K})\end{array}$ & $\begin{array}{l}\Delta G^{0}(\mathrm{~kJ} / \\
\mathrm{mol})\end{array}$ & $\begin{array}{l}\Delta H^{0}(\mathrm{~kJ} / \\
\mathrm{mol})\end{array}$ & $\begin{array}{l}\Delta S^{0}(\mathrm{~kJ} / \\
\mathrm{mol})\end{array}$ & $\begin{array}{l}E_{\mathrm{a}}(\mathrm{kJ} / \\
\mathrm{mol})\end{array}$ \\
\hline & & -135.46 & -0.381 & -38.33 \\
308 & -4.48 & & & \\
313 & -23.9 & & & \\
318 & -23.2 & & \\
323 & -14.34 & & \\
328 & -8.101 & & \\
333 & -5.865 & & & \\
338 & -3.041 & & & \\
\hline
\end{tabular}




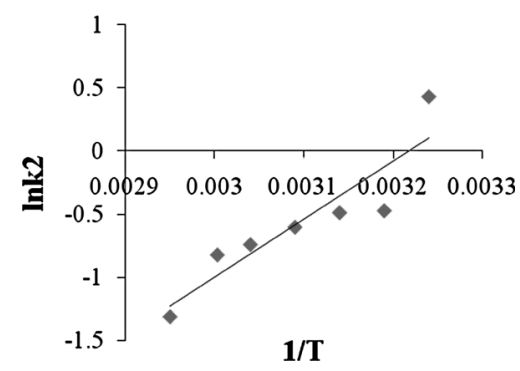

Fig. 17 Arrhenius equation plot for adsorption of lead onto ASBR

Table 7 Desorption of ASBR by $\mathrm{HNO}_{3}$ and $\mathrm{HCl}$ as desorbing solution at various concentrations

\begin{tabular}{lll}
\hline Desorbing solution & Concentration (mol/L) & Desorption (\%) \\
\hline $\mathrm{HNO}_{3}$ & 0.05 & 65.2 \\
& 0.1 & 72.1 \\
& 0.3 & 85.4 \\
& 0.5 & 97.3 \\
$\mathrm{HCl}$ & 0.05 & 57.8 \\
& 0.1 & 68.4 \\
& 0.3 & 77.6 \\
& 0.5 & 92.7 \\
\hline
\end{tabular}

2008). Therefore, lead sorption onto ASBR may be attributed to a chemical adsorption process. The negative value of $\Delta S^{0}$ suggests that the adsorption process is enthalpy driven. The $E_{\mathrm{a}}$ value calculated from the slope of the plot (Fig. 17) was found to be $-38.33 \mathrm{~kJ} / \mathrm{mol}$. The negative value of $E_{a}$ indicates that lower solution temperatures favors metal ion removal by adsorption onto the ASBR and the adsorption process is exothermic in nature.

\section{Desorption study}

A desorption study is also important, since it is useful in the recycling of the adsorbent and recovery of metal. Desorption of lead using different concentration of desorbing solutions $\left(\mathrm{HNO}_{3}\right.$ and $\left.\mathrm{HCl}\right)$ by disruption of coordination of metal ions and subsequent release from the ASBR surface into the desorption medium was studied. The results obtained are shown in Table 7 . The results showed that with increase in concentration of desorbing solutions $\left(\mathrm{HNO}_{3}\right.$ and $\mathrm{HCl}$ ), the desorption also increased and more than $90 \%$ of lead (II) ions were able to be desorbed from ASBR using $0.5 \mathrm{~mol} / \mathrm{L} \mathrm{HNO}_{3}$ and $\mathrm{HCl}$ solutions.

\section{Conclusion}

This study was focused on the adsorption of $\mathrm{Pb}$ (II) ions onto ASBR from aqueous solution. The operating parameters, such as solution $\mathrm{pH}$, adsorbent dose, temperature, stirring rate, initial $\mathrm{Pb}$ (II) concentration, and contact time were effective on the adsorption efficiency. The maximum adsorption of lead (II) ions was found at $\mathrm{pH}$ 6. The monolayer adsorption capacity of ASBR was found to be $1.567 \mathrm{mg} \mathrm{g}^{-1}$ at $25 \mathrm{mg} \mathrm{L}^{-1}$ initial lead concentration. The amount of lead (II) ions uptake ( $\mathrm{mg} / \mathrm{g}$ ) was found to increase with increase in contact time and adsorbent dose. The study on equilibrium sorption revealed that Freundlich isotherm model gave the best fit to experimental data. The nature of adsorption of lead (II) on ASBR was chemisorption as inferred from the Dubinin-Radushkevich (D-R) isotherm model. The adsorption kinetics followed pseudo second-order kinetic model with a good correlation. Intraparticle diffusion was not the sole rate-controlling factor. The calculated thermodynamic parameters showed the exothermic and spontaneous nature of the adsorption of lead onto ASBR. The present findings suggest that ASBR may be used as an inexpensive and effective adsorbent for the removal of lead ions from aqueous solutions without any treatment or any other modification.

Acknowledgments The authors are grateful to Dr. Aloke Ghosh, Reader, Department of Chemistry, Burdwan University, West Bengal, India for recording FTIR data and they also extend their gratitude to Dr. Srikanta Chakraborty, In charge of SEM, USIC, University of Burdwan, West Bengal for SEM study.

\section{References}

Abdel-Ghani NT, Hefny M, El-Chaghaby GAF (2007) Removal of lead from aqueous solution using low cost abundantly available adsorbents. Int J Environ Sci Tech 4(1):67-73

Abdel-Samad H, Watson PR (1998) An XPS study of the adsorption of lead on goethite $(\alpha-\mathrm{FeOOH})$. Appl Surf Sci 136(1-2):46-54

Ahluwalia SS, Goyal D (2005) Removal of heavy metals by waste tea leaves from aqueous solution. Eng Life Sci 5(2):158-162

Ahmad S, Khalid N, Daud M (2002) Adsorption studies of lead on lateritic minerals from aqueous media. Sep Sci Technol 37(2):343-362

Ahmad A, Rafatullah M, Sulaiman O, Ibrahim MH, Chii YY, Siddique BM (2009) Removal of $\mathrm{Cu}(\mathrm{II})$ and $\mathrm{Pb}$ (II) ions from aqueous solutions by adsorption onto sawdust of meranti wood. Desalination 247(1-3):636-646

Akar ST, Ozcan AS, Akar T, Ozcan A, Kaynak Z (2009) Biosorption of a reactive textile dye from aqueous solutions utilizing an agrowaste. Desalination 249(2):757-761

Akhtar M, Iqbal S, Kausar A, Bhanger MI, Shaheen MA (2010) An economically viable method for the removal of selected divalent metal ions from aqueous solutions using activated rice husk. Colloids Surf B: Biointerf 75(1):149-155

Anirudhan TS, Radhakrishnan PG (2008) Thermodynamics and kinetics of adsorption of $\mathrm{Cu}$ (II) from aqueous solutions onto a new cation exchanger derived from tamarind fruit shell. J Chem Thermodyn 40(4):702-709

Arief VO, Trilestari K, Sunarso J, Indraswati N, Ismadji S (2008) Recent progress on biosorption of heavy metals from liquids using low cost biosorbents: characterization, biosorption parameters and mechanism Studies. Clean: Soil, Air, Water 36(12):937-962 
Badmus MAO, Audu TOK, Anyata BU (2007) Removal of lead ion from industrial wastewaters by activated carbon prepared from periwinkle Shells (Typanotonus fuscatus). Turkish J Eng Environ Sci 31(4):251-263

BIS (1981) Tolerance limits for industrial effluents prescribed by Bureau of Indian Standards, IS 2490 (Part I), New Delhi

Blais JF, Mercier G, Durand A (2002) Lead and zinc recovery by adsorption on peat moss during municipal incinerator used lime decontamination. Environ Technol 23(5):515-524

Chen Z, Ma W, Han M (2008) Biosorption of nickel and copper onto treated alga (Undariapinnarlifida): application of isotherm and kinetic models. J Hazard Mater 155(1-2):327-333

Chowdhury S, Saha P (2010) Sea shell powder as a new adsorbent to remove Basic Green 4 (Malachite Green) from aqueous solutions: equilibrium, kinetic and thermodynamic studies. Chem Eng J 164(1):168-177

Coates J (2000) Interpretation of infrared spectra. In: Meyers RA (ed) A practical approach, encyclopedia of analytical chemistry. Welly, Chichester, pp 10815-10837

Crini G, Peindy HN, Gimbert F, Robert C (2007) Removal of C.I. Basic Green 4 (Malachite Green) from aqueous solutions by adsorption using cyclodextrin-based adsorbent: kinetic and equilibrium studies. Sep Purif Technol 53(1):97-110

Das B, Mondal NK (2011) Calcareous soil as a new adsorbent to remove lead from aqueous solution: equilibrium, kinetic and thermodynamic study. Univ J Environ Res Technol 1(4):515-530

Dimitrova SV, Mehandgiev DR (1998) Lead removal from aqueous soluitons by granulated blast- furnace slag. Wat Res 32(11):3289-3292

Dubinin MM, Zaverina ED, Radushkevich LV (1947) Sorption and structure of active carbons. Adsorption of organic vapors. J Phys Chem 21:1351-1362

Freundlich HMF (1906) Over the adsorption in solution. J Phys Chem $57: 385-471$

Goyal P, Sharma P, Srivastava S, Srivastava MM (2008) Saraca indica leaf powder for decontamination of lead: removal, recovery, adsorbent characterization and equilibrium modeling. Int J Environ Sci Technol 5(1):27-34

Gupta VK, Ali I (2004) Removal of lead and chromium from wastewater using bagasse fly ash-a sugar industry waste. J Colloid Interface Sci 271(2):321-328

Gupta VK, Gupta M, Sharma S (2001) Process development for the removal of lead and chromium from aqueous solutions using red mud-an aluminium industry waste. Wat Res 35(5):1125-1134

Han R, Lu Z, Zou W, Daotong W, Shi J, Jiujun Y (2006a) Removal of copper (II) and lead (II) from aqueous solution by manganese oxide coated sand: II. Equilibrium study and competitive adsorption. J Hazard Mater 137(1):480-488

Han R, Zou W, Li H, Li Y, Shi J (2006b) Copper (II) and lead (II) removal from aqueous solution in fixed-bed columns by manganese oxide coated zeolite. J Hazard Mat 137(2):934-942

Hanafiah MAK, Zakaria H, Wan Ngah WS (2009) Preparation, characterization, and adsorption behavior of $\mathrm{Cu}$ (II) ions on to alkali-treated weed (Imperata cylindrica) leaf powder. Water Air Soil Pollut 201(1-4):43-53

Ho YS, Mckay G (2000) The kinetics of sorption of divalent metal ions onto sphagnum moss peat. Wat Res 34(3):735-742

Ho YS, Ng JCY, McKay G (2001) Removal of lead (II) from effluents by sorption on peat using second-order kinetics. Separ Sci Technol 36(2):241-261

Imamoglu M, Tekir O (2008) Removal of copper (II) and lead (II) ions from aqueous solutions by adsorption on activated carbon from a new precursor hazelnut husks. Desalination 228(1-3):108-113

Kannan N, Veemaraj T (2009) Removal of Lead (II) Ions by adsorption onto bamboo dust and commercial activated carbons-A Comparative Study. E-J Chem 6(2):247-256
Kikuchi Y, Qian Q, Machida M, Tatsumoto H (2006) Effect of ZnO loading to activated carbon on $\mathrm{Pb}$ (II) adsorption from aqueous solution. Carbon 44(2):195-202

Kundu S, Gupta AK (2006) Arsenic adsorption onto iron oxide-coated cement (IOCC): regression analysis of equilibrium data with several isotherm models and their optimization. Chem Eng $\mathrm{J}$ 122(1-2):93-106

Lagergren S (1898) About the theory of so-called adsorption of soluble substances, der Sogenanntenadsorption geloster stoffe Kungliga Svenska Vetenska psalka de Miens Handlingar 24:1-39

Langmuir I (1918) The adsorption of gases on plane surfaces of glass, mica and platinum. J Am Chem Soc 40:1361-1368

Li YH, Wang S, Wei J, Zhang X, Xu C, Luan Z, Wu D, Wei B (2002) Lead adsorption on carbon nanotubes. Chem Phys Lett 357(3-4):263-266

Liu Y, Liu YJ (2008) Biosorption isotherms, kinetics and thermodynamics. Sep Purif Technol 61(3):229-242

Malakootian M, Almasi A, Hossaini $\mathrm{H}$ (2008) $\mathrm{Pb}$ and Co removal from paint industries effluent using wood ash. Int J Environ Sci Tech 5(2):217-222

Malik DJ, Strelko V Jr, Streat M, Puziy AM (2002) Characterisation of novel modified active carbons and marine algal biomass for the selective adsorption of lead. Wat Res 36(6):1527-1538

Martin MI, Lopez FA, Perez C, Lopez-Delgado A, Alguacil FJ (2005) Adsorption of heavy metals from aqueous solutions with byproducts of the steelmaking industry. J Chem Technol Biotechnol 80(11):1223-1229

Mckay G, Otterburn MS, Sweeney AG (1981) Surface mass transfer process during colour removal from effluent using silica. Wat Res 15(3):327-331

Mckay G, Blair HS, Finton A (1986) Sorption of metal ions by chitosan. In: Eddles $\mathrm{H}$, Hunt $\mathrm{S}$ (eds) Immobilization of ions by biosorption. Ellis Herwood, Chichester

Mishra PC, Patel RK (2009) Removal of lead and zinc ions from water by low cost adsorbents. J Hazard Mater 168(1):319-325

Mondal MK (2009) Removal of $\mathrm{Pb}$ (II) ions from aqueous solution using activated tea waste: adsorption on a fixed-bed column. J Environ Manage 90(11):3266-3271

Naeem K, Yawar W, Akhter P, Rehana I (2010) Atomic absorption spectrometric determination of cadmium and lead in soil after total digestion. Asian-Pac J Chem Eng. doi:10.1002/apj.535

Ofomaja AE, Unuabonah EI, Oladoja NA (2010) Competitive modeling for the biosorptive removal of copper and lead ions from aqueous solution by Mansonia wood sawdust. Bioresourc Technol 101(11):3844-3852

Papini MP, Bianchi A, Majone M, Beccari M (2002) Equilibrium modeling of lead adsorption onto a "red soil" as a function of the liquid-phase composition. Ind Eng Chem Res 41(8):1946-1954

Rhoades JD (1982) Cation exchange capacity. In: Methods of soil analysis part 2. Chemical and microbiological properties, 2nd ed. American Society of Agromony/Soil Science Society of America, Madison, WI

Saha P, Sanyal SK (2010) Assessment of the removal of cadmium present in wastewater using soil- admixture membrane. Desalination 259(1-3):131-139

Sari A, Citak D, Tuzen M (2010) Equilibrium, thermodynamic and kinetic studies on adsorption of $\mathrm{Sb}$ (III) from aqueous solution using low-cost natural diatomite. Chem Eng J 162(2):521-527

Senthilkumar P, Ramalingam S, Sathyaselvabala V, Dinesh Kirupha S, Sivanesan S (2011) Removal of copper(II) ions from aqueous solution by adsorption using cashew nut shell. Desalination 266(1-3):63-71

Slejko F (1985) Adsorption technology: a step by step approach to process. Eva Appl. Marcel Dekker, New York 
Tsai WT, Chen HR (2010) Removal of Malachite Green from aqueous solution using low-cost chlorella-based biomass. J Hazard Mater 175(1-3):844-849

Vogel AI (1984) A textbook of quantitative inorganic analysis. ELBS, London, pp 435-502

Weber WJ, Morris JC (1963) Kinetics of adsorption on carbon from solution. J Saint Eng Div Am Soc Civ Eng 89:31-60
Weerasooriya R, Aluthpatabendi D, Tobschall HJ (2001) Charge distribution multi-site complexation (CD-MUSIC) modeling of $\mathrm{Pb}$ (II) adsorption on gibbsite. Colloids Surf A Physicochem Eng. Asp 189(1):131-144

WHO (1996) Guidelines for drinking water and wastewater quality. Health criteria and other supporting information, 2nd ed., Geneva, vol 2, pp 152-279 